\title{
EFEKTIFITAS PERAN SEKRETARIS DALAM MELAKSANAKAN TUGAS DI KANTOR PPPPTK BISNIS DAN PARIWISATA (Pusat Pengembangan dan Pemberdayaan Pendidik dan Tenaga Kependidikan Bisnis dan Pariwisata (PPPPTK Bisnis dan Pariwisata)
}

\author{
Ratna Suminar ${ }^{1}$ \\ Dosen Prodi D-III Sekretari Universitas Pamulang \\ ratnasuminar2255@gmail.com \\ Endah Putri Wardani ${ }^{2}$ \\ Mahasiswi Prodi D-III Sekretari Universitas Pamulang
}

\begin{abstract}
Abstrak - Penulisan ini bertujuan untuk mengetahui serta menjelaskan Efektivitas peran sekretaris dalam menjalankan tugas. Diera globalisasi menuntut sekretaris berorganisasi dengan baik, profesi seorangSekretaris memegang peranan penting dalam operasional suatu perusahaan membantu pimpinan menjalankan tugasnya.Sekretaris adalah orang yang bertanggung jawab mempersiapkan berbagai macam tugas dan pekerjaan yang berhubungan dengan pimpinan, agar pimpinan dapat menjalankan perusahaannya dengan efesien dan efektif. Seorang sekretaris dalam kedudukannya sebagai seseorang yang terdekat dengan pimpinan puncak diarahkan untuk bertindak sebagai public relations yang baik untuk kepentingan internal maupun kepentingan eksternal perusahaan. Hal ini akan membawa posisi sekretaris menuju tanggung jawab dalam menumbuhkan citra baik perusahaan dimata masyarakat. Sekretaris dalam melaksanakan tugas membantu efektivitas pimpinan nampak pada kegiatan korespondensi, contoh seperti mengagendakan kegiatan pimpinan. Maka penulis memilih judul berkaitan dengan efektivitas peran sekretaris dalam melaksanakan tugas dikantor pppptk bisnis dan pariwisata.
\end{abstract}

\section{Kata Kunci : Efektifitas, Sekretaris, Public Relation}

Abstract - This writing aims to determine and explain the effectiveness of the role of the secretary in carrying out tasks. Diera globalization requires secretaries to organize well, the profession of a secretary plays an important role in the operations of a company to help the leader carry out his duties. The secretary is a person who is responsible for preparing various tasks and jobs related to the leader, so that the leader can run his company efficiently and effectively. A secretary in his position as someone closest to the top leadership is directed to act as a good public relations for internal and external interests of the company. This will bring the position of secretary to the responsibility in fostering a good image of the company in the eyes of the public. The secretary in carrying out the task of helping the effectiveness of the leadership appears in the correspondence activities, for example such as scheduling the leadership's activities. So the authors chose the title relating to the effectiveness of the role of the secretary in carrying out the duties in the office business and tourism pppptk.

Keywords: Effectiveness, Secretary, Public Relations 


\section{PENDAHULUAN}

\section{Latar Belakang Masalah}

Dalam menulis Tugas Akhir ini, Saya memilih Tempat "PPPPTK BISNIS DAN PARIWISATA" sebagai pusat pengembangan dan pemberdayaan pendidik dan tenaga kependidikan bisnis dan pariwisata.Praktek Kerja Industri merupakan salah satu bentukpenyelenggaraan pendidikan dan pelatihan bagi para mahasiswa, yangmemadukan antara pendidikan di Universitas dengan pendidikan di DuniaIndustri yang diperoleh dengan melakukan praktek kerja secara langsungdan terarah untuk menambah keahlian tertentu. Tujuan utama mahasiswa kejuruan sekretaris adalah mempersiapkan lulusan untuk dapat bekerja secaramandiri. Dalam rangka mempersiapkan calon-calon sekretaris professional, sangat penting untuk lembaga pendidikan seperti Universitas, Agar membekali para mahasiswanya dengan pengetahuan dan ketrampilan yang memadai. Sehingga setelah menyelesaikan pendidikan, para calon tenaga kerja ini mampu berkompetensi baik di negeri sendiri maupun di mancanegara. KarenaSeorangsekertaris memiliki peran yang penting dalam suatu perusahaan/organisasi, yang bersifat assisten atau mendukung. Dengan perkembangan zaman semakin dewasa ini peran sekertaris semakin pentingberdasarkan pada perkembangan tugastugas yang dilakuakan oleh seorang sekertaris. Sekertaris merunjuk kepada pekerjaan kantor yang tugasnya ialah melaksanakan secara rutin,seperti tugas-tugas Dinas atasan.

Dunia kesekretariatan sebagai suatu profesi yang telah jauh berkembangan sedemikian rupa sehingga berkembang pula menjadi suatu profesi yang sangat penting. Dengan berkembangannya tugas sekertaris, sekertaris harus mampu menyelesaikan pekerjaanyang dilimpahkan atau ditugaskan kepadanya dengan baik sekaligus bertanggung jawab terhadap pekerjaannya yang memerlukan penanganan yang berbeda-beda.Untuk itu seorang sekertaris segera menyelesaikan pekerjaannya agar tujuan/sasaran organisasi tercapai dengan berkerja seefisien dan seefektif mungkin.Di bidang administrasi,pengadaan kegiatan yang bersangkutan dengan fakultas, menjadi penyambung lidah antara pimpinan dengan pihak eksternal maupun internal dan menjadi pengganti pimpinan dalam pengambilan keputusan yang bersifat fakultif.Menjalankan tanggung jawabnya dalam mengelola kinerja. Kinerja adalah hasil atau tingkat seorang secara keseluruhan selama periode tertentu didalam melakukan tugas dibandingkan dengan berbagai kemungkinan, seperti standar hasil,target atau sasaran yang telah ditentukan terlebih dahulu dan disepakati bersama.Kinerja pada dasarnya adalah apa yang telah dilakukan atau tidak dilakukan. Oleh karena itu, agar mempunyai kinerja yang baik, 
seorang sekertaris harus mempunyai keinginan yang tinggi untuk mengerjakan pekerjaan dengan seefisien dan seefektif mungkin serta mengetahui pekerjaannya. Hal ini akan sangat berpengaruh terhadap kinerja perusahaan untuk masa sekarang dan masa yang akan datang. Mengingat pentingnya hal ini, maka penulis merasa tertarik untuk memilih judul: "EFEKTIVITAS PERAN SEKRETARIS DALAM MELAKSANAKAN TUGAS DI KANTOR PPPPTK BISNIS DAN PARIWISATA.

\section{Identifikasi Masalah}

Seorang Sekertaris mempunyai tugas penting dalam menyelesaikan pekerjaannya disuatu organisasi/perusahaan, maka dari itu seoarang sekertaris harus segera merencanakan pekerjaannya dan menyelesaikan pekerjaan dalam waktu singkat disamping harus tetap menjaga mutu pekerjaanya agar tidak menjadi penyimpangan dengan arti lain dapat diarahkan pada hal-hal yang sesuai dengan pembahasan penulisan maka masalah-masalah yang timbul dapat di identifikasikan antara lain:

1. Sekretaris dalam melaksanakan tugas belum efektif dan efisien di kantor PPPPTK BISNIS DAN PARIWISATA.

2. Sekretaris di kantor PPPPTK BISNIS DAN PARIWISATA belum memenuhi Syarat yang baik dalam meningkatkan profesionalisme kerja.

\section{Pembatasan Masalah}

Mengingat pemasalahan yang ada pada kantor PPPPTK BISNIS DAN PARIWISATA, Keterbatasan waktudan pengetahuan yang dimiliki oleh penulis serta untuk menghidari kesalahpahaman yang terjadi nantinya, Didalam Uraian singkat ini penulis berharap dapat mengamati lebih jauh mengenai :

"EFEKTIFITAS PERAN SEKERTARIS DALAM MELAKSANAKAN TUGAS

DI KANTOR PPPPTK BISNIS DAN PARIWISATA.”.

\section{Perumusan Masalah}

Dari pembatasan masalah tersebut maka fokus penulisan sudah sangat jelas, perumusan masalah dalam penulisan ini adalah 
1. Bagaimana tugas seorang sekertaris agar dapat bekerja secara efektif dan efisien pada kantor PPPPTK BISNIS DAN PARIWISATA?

2. Bagaimana meningkatkan Mutu Seorang sekretaris dikantor PPPPTK BISNIS DAN PARIWISATA?

\section{Tujuan dan Manfaat Penulisan}

Tujuan dilakukan penulisan ini adalah:

1. Untuk mengetahui gambaran jelas mengenai peran seorang sekertaris agar dapat bekerja secara efektif dan efisien dikantor PPPPTK BISNIS DAN PARIWISATA

2. Untuk mengetahui bagaimana meningkatkan mutu kerja seorang sekretaris dikantor PPPPTK BISNIS DAN PARIWISATA.

Manfaat dari penulisan ini adalah :

1. Agar dapat mengetahui jelas mengenai peran seorang sekretaris yang berkerja secara efektif dan efisien dikantor PPPPTK BISNIS DAN PARIWISATA.

2. Agar mengetahui bagaimana meningkatkan mutu kerja seorang sekretaris dikantor PPPPTK BISNIS DAN PARIWISATA.

\section{LANDASAN TEORI}

\section{Pengertian Sekretaris}

Sekretaris adalah orang yang bertanggung jawab mempersiapkan berbagai macam tugas dan pekerjaan yang berhubungan dengan pimpinan, agar pimpinan dapat menjalankan perusahaannya dengan efisien dan efektif. Sekretaris merupakan profesi yang kini banyak diminati. Disamping memberikan prospek karir yang baik, Kesempatan kerja yang ada untuk Sekretaris kini lebih terbuka, lebih dari itu kedudukan sekretaris diperusahaan membantu pimpinan dan bertanggung jawab atas kegiatan kantor agar berjalan baik.Sekretaris memegang peranan penting dalam membantu pimpinan menjalankan tugasnya dan menyimpan rahasia pimpinan dan perusahaan karena sedikit banyak rahasia tersebut diketahui oleh sekretaris untuk bisa selalu menjaga itu dari siapapun yang berkepentingan terhadapnya hal ini disebabkan kebijakan awal yang dikeluarkan oleh pimpinan atau perusahaan sedikit banyak akan diketahui 
oleh sekertaris. Karena tugas sekretaris adalah membantu pimpinan dalam meringankan tugastugasnya.Sekretaris adalah seorang yang mempunyai tugas dan tanggung jawab yang besar dalam membantu kelancaran kegiatan kantor, terutama dalam hal administrasi yaitu tugastugas ketatausahaan yang meliputi kegiatan korespondensi, contoh nya seperti mengarsipkan surat atau dokumen, menelepon dan menerima telepon, membuat perjanjian dan lain lainnya.

\section{Peranan Sekretaris}

Sekretaris memegang peranan yang penting dan dapat menentukan berhasil tidaknya tujuan perusahaan.Pentingnya peranan seorang sekretaris ini tentunya sesuai dengan jabatan sekretaris pada masing-masing organisasi.Pada dasarnya setiap sekretaris mempunyai peranan yang sama, yaitu membantu kelancaran pelaksanaan tugas-tugas pimpinan. Dalam melaksanakan tugas tersebutberjalan secara efisien dan efektif. Peran sekretaris secara umum dapat diketahui sebagai berikut:

Peran Sekretarissecara secara umum sebagai berikut :

1. Peran Sekretaris terhadap atasan

a. Sebagai faktor penunjang dalam keberhasilan pekerjaan dan cerminan pimpinan bagi bawahan.

b. Sebagai perantara atau saluran komunikasi dan pembinaan hubungan yang baik bagi orang yang ingin berhunbungan dengan pimpinan.

c. Sebagai sumber informasi yang diperlukan pimpinan dalam memenuhi fungsi, tugas, dan tanggung jawab.

d. Sebagai alternative pemikiran pimpinan dalam ide-ide.

2. Peran Sekretaris terhadap bawahan

Peran sekretaris terhadap bawahan merupakan penilaian dari bawahan sehingga sikap dan tingkah laku sekretaris yang ramah dan komunikatif akan memberikan suatu suasana hubungan kerja yang baik bagi bawahan sehingga segala permasalahan dapat didiskusikan dan dicari permasalahannya.

Peran Sekretaristerhadap bawahan, tampak dalam :

a. Memberikan rasa bangga dan puas kepada pegawai bawahan dalam menjalankan pekerjaan. 
b. Menerima pendapat dan usul dari bawahan dari berbagai masalah.

c. Memberikan motivasi kerja kepada pegawai bawahan sehingga pekerjaan dapat berjalan lancar dan berhasil.

d. Sebagai Mediator antara bawahan dan pimpinan.

\section{Peran Sekretaris dalam Human Relations}

Human Relations merupakan hal yang peting dalam organisasi atau perusahaan karena perusahaan tidak pernah lepas dari faktor manusia yang memiliki keaneragaman sifat. Sekretaris sebagai bagian dari organisasi selalu berhadapan dengan pimpinan dan bawahan dan orang-orang dari luar perusahaan yang memiliki sifat dan kepentingan yang berbedabeda.

Dengan mengetahui sifat-sifat dan kepentingan seseorang lewat human relations, sekretaris akan cepat dan mudah untuk mengatasi setiap orang yang mempunyai kepentingan tersebut. Sikap-sikap yang sangat bermanfaat dalam human relations, yaitu :
a. Bersikap sabar dan tenggang rasa terhadap pekerjaan dan permasalahan yang dihadapi.
b. Saling pengertian
c. Tegas dan adil
d. Obyektif

\section{Sekretaris Dan Ruang Lingkup}

Sekretaris berdasarkan luas lingkup perusahaan digolongkan menjadi dua macam sekretaris

1. Executive Secretary (sekretaris eksekutif)

Sekretaris yang berfungsi sebagai manajer karena secara formal menjalankankan fungsi manajer. Sekretaris ini memiliki pegawai atau bawahan, Misalnya : Sekretaris Jendral, Sekretaris yayasan.

2. Private Secretary (sekretaris pribadi)

Sekretaris pribadi adalah sekretaris yang melaksanakan aktifitas kantor untuk membantu kepentingan seorangpemimpin tertentu dan bersifat pribadi.

Sekretaris pribadi kerap kali dituntut berkerja mandiri oleh seorang pemimpin, berperan semata-mata sebagai pembantu dan tidak memiliki bawahan.Misalnya sekretaris manajer, sekretaris Direktur, sekretaris Artis, dan sebagainya.

Dari dilihat dari ruang lingkup sekretaris diatas dapat disimpulkan bahwa sekretaris mempunyai berbagai macam jenis sekretaris, dan pada intinya jenis-jenis sekretaris tersebut 
adalah membantu pimpinanya dalam melaksanakan perkerjaan. Disamping itu besar kecilnya skala perusahaan ikut mempengaruhipendelegasian tugas dari pimpanan ke sekretaris.

1. Secretary in Small Office ( Sekretaris dikantor kecil )

Sekretaris yang berkerja pada perusahaan dengan skala kecil biasanya memiliki ruang lingkup pekerjaan yang lebih beraneka ragam, kadang kala sekretaris harus mengerjakan pekerjaan yang seharusnya dikerjakan oleh staf bidang lainnya.Tetapi karena keterbatasan staf yang berkerja maka pekerjaan yang akan dilakukan dan dirangkap oleh sekretaris.

2. Secretary in Medium Office ( Sekretaris di kantor menengah )

Sekretaris yang berkerja pada perusahaan dengan skala menengah biasanya memiliki ruang lingkup pekerjaan yanag lebih jelas (well defined).Pada perusahaan dengan skala seperti ini, sekretaris mungkin melakukan pekerjaan rangkap sebagai receptionist.

3. Secreatary in Large Office ( Sekretaris dikantor besar)

Sekretaris yang bekerja pada perusahaan dengan skala besar biasanya memiliki ruang lingkup pekerjaan yang suadah ditentukan dengan baik (very well defined).Sekretaris yang bekerja pada perusahaan ini memiliki level atau tingkatan yang berbeda-beda. Biasanya pekerjaan ini mempunyai ruang lingkup yang lebih luas seperti menjadi perantara komunikasi antarapimpinan dan pihak luar(klien),melakukan presentasi menggantikan pimpinan,turut serta membantu rencana organisasi bersama pimpinan.

\section{Etika Dan Pengembangan Kepribadian}

ETIKA dalamKamus Besar Bahasa Indonesia yang baru (Departemen pendidikan dan Kebudayaan, 1988 -mengutip dari Bertens 2000), mempunyai arti :

1. Ilmu tentang apa yang buruk dan tentang hak dan kewajiban moral;

2. Kumpulan asas atau nilai yang berkenaan dengan aklak;

3. Nilai mengenai benar dan salah yang dianut suatu golongan atau masyarakat.

\section{Etika Sekretaris}

Etika sekretaris pada intinya hanya meliputi Larangan dan Ajuran.

Sekretaris harus mempunyai Etika yang baik agar sekretaris bisa bersikap menghormati kepada pimpinan maupun bawahan tanpa memandang status, dengan etika yang baik berarti sekretaris telah mengetahui norma-norma,nilai-nilai, kaidah-kaidah yang diterima 
ditaati oleh sekretaris. Yang berupa peraturan-peraturan atau hal-hal yang sudah merupakan kebiasaan yang baik dan dianggap sudah diketahui dan perlu atau harus dilaksanakan.

Hal-hal yang anjura/saran dilakukan oleh seseorang yang berprofesi sebagai Sekretaris atau bahkan karyawan :

1. Selalu berusaha membangun posting (positif thinking).

2. Padai membawa diri dan menyusaikan diri pada berbagai situasi dan kondisi.

3. Rencakan pekerjaan, dan nilai kualitas kerja anda dari hari kehari.

4. Mempelajari gaya bekerja, kebiasaan, kesukaan dan yang tidak disukai oleh pimpinan.

5. Rajin berkerja, sopan, tulus dan jujur.

6. Biasakan diri untuk bersikap Royal pada perusahaan.

7. Laksanakan intruksi Pimpinan dengan cepat dan tepat.

8. Bersikaplah sebagai orang yang professional, yang bisa meningkatkan citra diri sendiri dan profesi.

9. Biasakan senantiasan menciptakan suasana kerja yang mengembirakan.

10. Biasakan diri mengucapkan salam (selamat pagi, siang, sore,malam. Bukan ucapan PERMISI).

Sedangkan berikut ini adalah beberapa hal -hal yang sebaiknya tidak dilakukan oleh seorang yang berprofesi sekretaris (Larangan) atau bahkan seorang karyawan :

1. Membentuk sebuah kelompok/komunitas yang bertentangan dengan tujuan perusahaan.

2. Menggunakan fasilitas kantor tanpa ijin dan tidak bertanggung jawab (misal: menggunakan telepon kantor untuk pacaran).

3. Menjilat atasan, mendepak bawahan.

4. Sering menunda pekerjaan

5. Pulang sebelum jam kerja berakhir.

6. Bergegas pulang, sementara Pimpinan masih berada dikantor.

7. Tidak masuk kerja karena alasan yang tidak bisa dipertanggung jawabkan.

8. Boros memakai peralatan kantor (misal: pemakaian kertas kantor yang berlebihan)

9. Tidak terlalu pendiam, juga tidak terlalu cerewet.

10. Menggunakan fasilitas kantor untuk keperluan pribadi (misal: menggunakan mobil kantor untuk jalan-jalan). 


\section{Pengembangan Kepribadian}

Pengembangan kepribadiandan prilaku manusia. Sebagai seorang karyawan perusahaan, kepribadian, penampilan, karakter atau sifat, dan tikah laku yang baik perlu dimiliki agar dapat mengatur bagaimana berhubungan dengan orang lain, Kepribadian merupakan salah satu faktor dominan yang menentukan sikap bekerja sama secara efektif dan saling menguntungkan serta membentuk citra positif bagi perusahaan.

Dapat kita jabarkan berikut point utama yang dapat digunakan untuk pembentukan pribadi atau pengembangan diri adalah sebagai berikut :

1. Percaya pada diri sendiri

2. Sikap optimis

3. Sikap hati-hati

4. Selalu tersenyum dan bersikap toleransi

5. Mengoreksi diri sendiri

6. Menghargai pendapat orang lain

7. Ketahanan terhadap cobaan

8. Ambisi

9. Kepekaan social (empati)

10. Menujukan kemauan untuk selalu belajar

\section{Efektivitas Sekretaris}

\section{Pengertian Efektivitas}

Sekretaris memiliki peran yang penting dalam suatu organisasi atau perusahaan yaitu membantu kelancaran pelaksanaan tugas-tugas pimpinan, dalam melaksanakan tugas agar berjalan secara efisien dan efektif.Kata efektif sering kali dicampur adukkan dengan kata efisien walaupun artinya tidak sama, sesuatu yang dilakukan secara efisien belum tentu efektif. Efektif adalah dengan input yang sama dihasilkan ouput yang lebih besar sedangkan efisien adalah dengan ouput yang sama digunakan input yang lebih kecil. Efektif dan efisien mempunyai persamaan yaitu sama - sama berbicara perbandingan atau rasio antara input dengan ouput. Sedangkan Efektivitas adalah pencapaian secara tepat atau memilih tujuan yang tepat dari serangkaian tugas. Efektifitas bisa juga diartikan sebagai pengukuran keberhasilan dalam pencapaian tujuan - tujuan yang telah ditentukan 
seseorang. Sekretaris dan kantor merupakan salah satu kesatuan yang utuh dan bahkan sekretaris adalah kunci kedua setelah menejer atau pimpinan. Segala urusan perkantoran mulai dari urusan surat-menyurat sampai masalah keputusan pimpinan sangat mempunyai pengaruh efektivitas peran terhadap sekretaris. Diluar hal itu menyelesaikan segala urusan kantor terletak pada kepintaran sekretaris. Berdasarkan jabatan seorang sekretaris harus mampu melaksanakan tugasnya.

2. Tujuan efektivitas sekretaris

Tujuan dari efektivitas sekretaris yaitu:

a. Mencegah dan mengurangi terjadinya tindakan-tindakan yang tidak diharapkan yang dapat mengganggu jalannya pekerjaan.

b. Mencapai produktivitas yang tinggi, perusahaan harus dapat menimbulkan semangat kerja yang tinggi dari sekreatris.

c. Agar dapat Membangun citra perusahaan

d. Mengembangkan rencana-rencana untuk mencapai tujuan-tujuan perusahaan

\section{Karakteristik Efektivitas}

Efektivitas adalah tingkat pencapaian tujuan organisasi.Efektivitas organisasi adalah keseimbangan atau pendekatan secara optimal pada pecapaian tujuan.Adapun konsep tingkat efektivitas sekretaris tersebut melaksankan kegiatan atau fungsi-fungsi sehingga tujuan yang telah ditetapkan dapat tercapai dengan menggunakan secara optimal.

Efektivitas yang harus dimiliki oleh seorag sekreatris dan karyawan dalam melaksanakan tugasnya harus memiliki kriteria dan ukuran sebagai berikut:
a. Kemampuan menyesuaikan diri
b. Motivasi
c. Prestasi kerja
d. Kepuasan kerja

\section{Tugas dan Tanggung Jawab Sekretaris}

Dalam sebuah kantor seorang pimpinan membutuhkan sekretaris untuk membantu meringankan tugas-tugas dan beban pimpinan, terutama dalam tugas-tugas yang bersifat rutin dan opersiaonal, sehingga pemimpin berkosentrasi dan mengurus tugas-tugas menejerialnya dengan baik. Maka seorang pemimpin akan sangat memerlukan bantuan sekretaris dalam 
melaksanakan pekerjaan kantor.Tugas Sekretaris adalah membantu pimpinannya dalam melaksanakan tugas-tugas pimpinanya.

1. Macam-macam Tugas Sekretaris

Dibawah ini tugas-tugas sekretaris dapat diuraikan sebagi berikut:

a. Tugas Rutin

Yaitu tugas umum yang hamper setiap hari dilakukan/dihadapi, Tanpa harus menunggu peritah khusus dari pimpinan.

Adapun tugas rutin sekretaris adalah :

1) Membuka surat

2) Menerima dikte

3) Mengetik surat

4) Menerima dan melayani tamu

5) Menerima dan menangani telepon

6) Menerima fax masuk

7) Menata arsip dan surat

8) Mengangendakan surat masuk dan surat keluar

9) Mengagendakan kegiatan pimpinan

b. Tugas-Tugas Khusus

Yaitu tugas yang diperintahkan langsung oleh pimpinan kepada sekretaris dengan penyelesainnya secara khusus dan biasanya berdasarkan unsur kepercayaan pimpinan kepada sekretarisnya bahwa ia mampu dan bisa diandalkan untuk menyelesikan suatu tugas tertentu.

Tugas ini meliputi:

1) Menyusun surat rahasia (confidental)

2) Menyusun makalah, pidato untuk pimpinan

3) Menyusun acara pertemuan bisnis

4) Mempersiapkan rapat

5) Menyiapkan dokumen perjalanan dinas pimpinan

6) Mengurus perjalanan dinas pimpinan

7) Mengkonsep surat perjanjian kerjasama dengan relasi atau instansi luar

8) Memproses surat keluar dan surat masuk pimpinan

9) Membuat dan mendistribusikan notulen rapat 


\section{c. Tugas Istimewa}

Yaitu tugas yang menyangkut keperluan pimpinan, antara lain :

1) Membetulkan letak posisi alat tulis pimpinan serta perlengkapan yang diperlukan.

2) Mengahadiri rapat-rapat dinas, sebagai pendamping pimpinan selama mengadakan pertemuan bisnis.

3) Mengadakan pemeriksaan peralatan kantor, mana yang perlu diperbaiki dan mana tidak perlu diperbaiki atau penambahan alat-alat dan sarana kantor.

4) Bertindak sebagai penghubung untuk meneruskan informasi kepada relasi.

\section{d. Tugas Sosial}

1) Mengurusi rumah tangga kantor.

2) Mengatur penyelenggaraan resepsi untuk kantor pimpinan baserta pengurusan undangannya.

3) Melaksanakan tugas-tugas lain sesuai perintah atasan.

\section{e. Tugas Keuangan}

Biasanya sekretaris mengurui keuangan kantor yang dinamakan pettycash(uang cadangan/kas kecil). Tugas keuangan ini antara lain :

1) Menangani urusan keuangan pimpinan di Bank, Misalnya : penyampaian penyimpanan uang dibank, penarikan cek, pengambilan uang dari Bank.

2) Membayar rekening-rekening, pajak, sumbangan dana atas nama pimpinan.

3) Membayar iruan keamanan kantor.

4) Menyimpan Catalan pengeluaran sehari-hari untuk mimpinan dan penyediaan dana untuk keperluan sehari-hari.

\section{f. Tugas Resepsionis}

Tugas Sekretaris sebagai resepsionis, yaitu :

1) Menerima dan Menjawab telepon serta mencatat pesan lewat telepon.

2) Menerima tamu yang akan bertemu dengan pimpinan.

3) Mencatat janji-janji untuk pimpinan.

4) Melayani tamu-tamu pimpinan 
g. Tugas Insidental

Tugas Insidental merupakan pekerjaan yang tidak rutin dilalukan oleh sekretaris, meliputi :

1) Menyiapkan agenda rapat, menyiapkan laporan, menyiapkan pidato atau pernyataan pimpinan.

2) Mewakili pimpinan dalam berbagai resepsi atau pertemuan.

3) Mengoreksi bahan-bahan cetakan, misalnya : brosur, undangan, formulir, dan daftar yang dikonsep oleh perusahaan.

4) Membuat ikhtisar dari berita-berita dan karangan yang termuat dalam surat kabar, majalah, brosur, dan media- media lain yang ada kaitannya dengan kepentingan perusahaan.

h. Tugas sekretaris dalam Business Meeting (pertemuan bisnis)

Pertemuan bisnis (business meeting) ini terjadi ketika dua orang atau lebih saling menerima dan memberikan sesuatu berupa informasi, menyimak kembali kemajuan, memecahkan masalah dan menciptakan yang baru.Tugas inilah yang cukup berat dan melelahkan bagi sekretaris untuk mengorganisir pertemuan-pertemuan tersebut.

\section{Berdasarkan pendapat para ahli mengenai tugas sekretaris adalah sebagai berikut :}

1. Menurut H.Donald

Menyatakan bahwa hal-hal kedudukan pimpinan dan situasi organisasi perusahaan akan menetukan sebagaian besar tugas-tugas sekretaris.

Hal-hal yang dimaksud adalah :

a. Menyalin atau mengisi transkip dari stenografi atau warkat-warkat dari mesin dikte.

b. Membuat cacatan pertemuan, menyusun dan memelihara arsip khusus.

c. Menyelesaikan urusan apapun dari masalah pribadi pimpinan yang diminati, dan lainlain.

2. Menurut M.Braum dan Ramon C. dari Portugal

Tugas dan tanggung jawab sekretaris tidaklah sama persis tetapi dapat dikelompokan sebagai berikut :
a. Merencanakan perkerjaan
b. Menerima tamu
c. Mengurus surat masuk dan surat keluar
d. Menyiapkan pertemuan atau konferensi, dan lain-lain. 


\section{Tanggung Jawab Sekretaris}

Selain sekretaris bertanggung jawab atas pekerjaanya ada tanggung jawab lain yang harus dilaksanakan yaitu :

1. Personal Responsibility (Tanggung Jawab Induvidu)

Sekretaris bertanggung jawab terhadap perfomansi diri sendiri dan upaya pengembangan kea rah yang lebih berkualitas. Dengan "Mengelola" diri sendiri supaya dapat tampil dengan performasi prima dalam pelaksanaan tugas pokok sehari-hari, antara lain :

a. Mempermudah dan memperlancar kerja pimpinan melalui pengaturan waktu dan distribusi informasi yang efisien.

b. Mendistribusikan informasi dar kantor pimpinan secara jelas akurat

c. Mendukung kelancaran alur kerja antara kantor pimpinan dengan bagian-bagian lainnya.

d. Memberikan peluang kepada pimpinan untuk lebih berfokus pada hal-hal strategis dan memiliki dampak jangka panjang

e. Memberikan masukan positif dan insiatif untuk perbaikan perusahaan.

2. Internal Responsibility (Tanggung Jawab Dalam)

Sekretaris bertanggung jawab terhadap upaya pencapaian superioritas kinerja kantor dan pengaruhnya terhadap kinerja perusahaan.

Tanggung jawab ini terwujud melalui aktivitas :

a. Mengelola sumber daya kantor termasuk keuangan.

b. Menciptakan suasana (fisik dan mental) yang mendukung kelancaran kerja.

c. Mendukung penciptaan budaya kerja yang positif

d. Membantu menciptakan "kelompok informal positif dilingkungan peruusahaan.

e. Mengelola anak buah untuk meningkatakan efetifitas dan efisiensi kerja dikantor.

3. Networking Responbility (Tanggung Jawab Cabag Perusahaan)

Tanggung jawab sekretaris untuk meluaskan wawasan dan jalinan perusahaan dengan tujuan peningkatan daya saing. Perwujudannya adalah melalui upaya memperluas network perusahaan, mengatur dan mengawasi pelaksanaan acara-acara dan informal yang diselenggarakan oleh kantor kaitanya dengan upaya mempertahankan dan berpartisipasi dalam mengembangkan citra perusahaan (A.B Susanto, 1997:14-15). 
a. Bertanggung jawab atas berhasilnya perusahaan tempat dia berkerja. Dalam peran aktifnya membantu kelancaran tugas-tugas pimpinan sehingga dapat tercapai tujuan yang telah ditetapkan.

b. Tanggung jawab hukum seorang sekretaris. Salah satu segi penting dari jabatan sekretaris, walaupun kemungkinan besar tidak tercantum dalam peraturan tertulis, adalah tanggung jawab hukumnya sebagai perantara, berarti sekretaris berperan menjadi wakil pimpinan dalam urusan bisnisdengan pihak ketiga, karena sekretaris mempunyai wewenang ini.Jadi sekretaris harus bertindak hati-hati dan bertanggung jawab.

\section{Berikut ini hal-hal yang perlu diperhatikan oleh Sekretaris :}

1. Sekretaris tidak boleh membocorkan rahasia pimpinan baik masa berkerja atau masa kerja berakhir.

2. Sekretaris tidak berkecipung dalam suatu usaha saingan kecuali mendapat ijin dari pimpinan.

3. Sekretaris tidak boleh melakukan jual beli dengan perusahaan demi keuntungan pribadi, kecuali bila perusahaan memberikan ijin.

4. Sekretaris harus mengikuti secara cermat dan tepat semua instruks pimpinan dalam melaksanakan tugas rutin.

5. Keterangan dari pimpinan mengenai batas-batas yang jelas dan pasti mengenai wewenang sekretaris sangat diperlukan dan jangan sekali-kali bertindak melampui batasbatas tersebut. (Thomas W Bratawidjaja, 1996: 87-88).

\section{HASIL DAN PEMBAHASAN}

\section{Sejarah PPPPTK BISNIS DAN PARIWISATA}

Pusat pengembangan dan pemberdayaan pendidikan dan Tenaga kependidikan selanjutnya di sebut PPPPTK adalah unit pelaksanaa teknis dilingkungan kementreian Pendidikan dan Kebudayaan dibidang pengembangan dan pemberdayaan pendidikan an tenaga kependidikan, berada dibawah dan tanggung jawab kepada Badan Pengembangan Sumber Daya Manusia Pendidikan dan Kebudayaan dan Penjaminan Mutu Pendidikan. Di lingkungan Kementrian Pendidikan dan Kebudayaan terdapat 12 PPPPTK, dan mempunyai tugas melaksanaan pengembangan dan pemberdayaan pendidikan dan tenaga kependidikan, sesuai 
dengan bidangnya (pasal 1 permendikbud Nomor: 41 Tahun 2012). Pusat Pengembangan dan Pemberdayaan Pendidikan dan Tenaga Kependidikan Bisnis dan Pariwisata (PPPPTK Bisnis dan Pariwisat) Pada awalnya bernama Pusat Pengembangan Penataran Guru (PPPG) Kejuruan menempati gedung Pusat Latihan Pendidkan Kesetehteraan Keluarga (PL-PKK didirikan pada tahun 1962, berfungsi sebagai penyelenggara program latihan bagi guru-guru PKK pada sekolh kejuruan) yang berlokasi di Jalan Taman Margasatwa, Ragunan, Pasarmnggu, Jakarta selatan.

Pada Tanggal 23 Januari 1990, PPPPTK Bisnis dan Pariwisata yang saat itu masih masih bernama PPPG Kejuruan di pindahkan ke loksi baru di jalan Raya Parung Km. 22-23 Bojongsari, Depok-Jawa Barat dan menempati lahan selus 12 hektar dengan bangunan seluas 2,9 hektar. Sejalan dengan berjalanan waktu dan perkembangan zaman, PPPG “ Kejuruan” yang awalnya ada 2 PPPG "Kejuruan" yaitu PPPG Teknologi Bandung dan PPPG Kejuruan Jakarta (Sesuai SK Mendikbud Nomor: 0205/U/1978) Pada tahun 1990 terjadi perampingan organisasi PPPG, dan bertambahan 4 PPPG “Kejuruan” yaitu PPPG Teknologi Medan , PPPG Teknologi Medan, PPPG Teknologi Malang, PPPG Pertanian Cianjur, dan PPPG Kesenian Yogyakarta) sebagaimana SK Mendikbud Nomor 0529/O/1990. Dlam perjalannya, PPPG "Kejuaruan" secara bertahap berubah menjadi subsistem dari pengembangan pendidikan kejuruan Indonesia.Oleh karena itu, maka perencanaan pengembangan pendidikan kejuruan (Sekolah Menengah Kejuruan) dan berbagai program serta kegiatan dibahas bersama antara Direktorat Dikmenjer dengan PPPG “Kejuruan”.Berdasarkan Permendiknas No. 8 Tahun 2007 tanggal 13 Febuaari 2007, PPPG Kejuruan berubah nama menjadi Pusat Pengembangan dan pemberdayaan pendidikan dan Tenaga Kependidikan (PPPPTK) Bisnis dan Pariwisata.

Dengan terjadinya perubahan pada tingkat Kementrian (menjadi Kementrian Pendidkan dan Kebudayaan) dan esolan I (Khususnya Badan Pengembangan Sumber Daya Pendidikan), pada tahun 2012 tanggal 7 Juni diterbitkan Permendikbud Nomor 41 tahun 2012 tanggal 7 Juni 2012 tentang Organisasi dan Tata Kerja Pusat Pengembangan dan Pemberdayaan Pendidikan dan Tenaga Kependidikan sebagaimana dalam Berita Negara Repbulik Indonesia Tahun 2012 Nomor 597.

Sejak berdirinya sampai sekarang, PPPTK Bisnis dan Pariwisata telah mengalami lima kali pergantian. Pimpinan, yaitu :

1. Drs.Surajiman (Kepala PPPG Kejuruan Periode Tahun 1978 - 1984);

2. Ir.Winnetou Nowawi (Kepala PPPG Kejuruan Periode Tahun 1984 - 1997);

3. Ir.Sartono, MM (PPPG Kejuruan Periode Tahun 1997 - 2002); 
4. Drs.Andono (Kepala PPPG Kejuruan Periode Tahun 2002 - 2006);

5. Drs.Suwondo MS, MM, M.Si, (Kepala Kejuruan periode Tahun 2006 - 2007 dan Kepala PPPPTK Bisnis dan pariwisata Periode Tahun 2007 - 2009);

6. Ir. Giri Suryatman, PLT Kepala PPPPTK Bisnis dan Pariwisata Tahun 2010;

7. Dr. Murtoyo, MM (Kepala PPPPTK Bisnis dan Pariwisata periode Tahun 2011 pertengahan 2016)

8. Dr. Hj. Djuariati Azhari M.Pd. (Kepala PPPPTK Bisnis dan Pariwisata periode Desember 2016 s.d sekarang).

\section{Kebijakan Mutu}

PPPPTK Bisnis dan Pariwisata memberikan pelayanan pendidikan dan pelatihan berstandar internosional, peneletian dan pengembangan, serta layanan konsultan kepada pendidikan dan tenaga kependidikan serta masyarakat di bidang bisnis dan pariwisata.

Untuk mewujudkan kebijakan tersebut secara efektif dan efisien, seluruh pimpinan dan karyawan bertekad untuk :

1. Menerapkan system menajemen mutu ISO 9001:2008 pada semua kegiatan;

2. Memberikan pelayanan prima pada semua kegiatan layanan jasa pendidikan dan;

3. Selalu meningkatkan mutu pelayanan,menijau dan memperbaiki system manajemen mutu secara berkelanjutan.

Dalam melaksanakan kegiatan sehari-hari, PPPPTK Bisnis dan Pariwisata menerapkan dan menjunjung tata nilai berikut :

1. Ketelandanan

2. Pelayanan Prima

3. Inovasi

4. Kebersamaan

5. Saling Percaya dan Menghargai.

\section{Visi dan Misi PPPPTK BISNIS DAN PARIWISATA}

Visi :Menjadi lembaga pengembangan dan pemberdayaan penndidikan dan tenaga kependidikan bisnis dan pariwisata bertaraf Internasional berbasis budaya bangsa.

Misi : 
Memberikan layanan prima bagi pendidik dan tenaga kependidikan melalui fasilitas peningkatan kompentensi bertaraf Internasional, penelitian dan pengembangan, serta layanan konsultasi berbasis budaya bangsa.

\section{Tugas dan Fungsi PPPPTK Bisnis dan Pariwisata}

\section{Tugas PPPPTK}

PPPPTK mempunyai tugas melaksanakan pengembangan dan pemberdayaan pendidikan dan tenaga kependidikan sesuai dengan bidangnya (pasal 2)

2. Fungsi PPPPTK

a. Penyusunan program pengembangan dan pemberdayaan pendidikan dan tenaga kependidikan ;

b. Pengelolaan data informasi peningkatan kompentensi pendidikan dan tenaga kependidikan ;

c. Fasilitas dan pelaksanaan peningkatan kompetensi pendidik dan tenaga kependidikan ;

d. Pelaksanaan kerja sama di bidang pengembangan dan pemberdayaan pendidik dan tenaga kependidikan ;

e. Evaluasi program dan fasilitas peningkatan kompentesi pendidik dan tenaga kependidikan ; dan

f. Pelaksanaan urusan administrasi PPPPTK (Pasal 3)

\section{Strategi Organisasi}

Untuk mewujudkan visi dan misi PPPPTK Bisnis dan Pariwisata menetapkan strategi organisasi secara makro yang meliputi:

1. Membangun organisasi dan menejemen yang tangguh, lentur, kreatif dan inovatif dilandasi prinsip organisasi pembelanjaran untuk mewujudkan visi, misi dan tujuan PPPPTK Bisnis dan Pariwisata, kebijakan dan program Badan pengembangan Sumber Daya Manusia Pendidikan dan Kebudayaan dan Penjaminan Mutu Pendidikan, dan kebijakan Kemdikbud (tiga pilar kebijakan);

2. Meningkatkan potensi dan kapasistas seluruh sumberdaya manusia sehingga mampu menghadapi berbagai perubahan dan dinamika global

3. Membangun budaya organisasi dan iklim kerja yang kondusif berlandaskan nilai budaya bangsa Indonesia ;

4. Menjalin kerjasama kemitraan dengan pihak - pihak terkait untuk membangun jaringan lingkup regional, nasional maupun internasinal ; 
5. Mengembangkan produk - produk diklat dalam bidang bisnis dan pariwisata ;

6. Memberdayakan seluruh sumberdaya PPPPTK Bisnis dan pariwisata secara kreatif , inovatif, efektif dan efesien untuk meningkatkan kualitas layanan sehingga memuaskan seluruh stakeholder.

\section{Faktor Penentu Keberhasialan}

1. Sumberdaya manusia yang professional dan berkomitmen tinggi dengan penghargaan yang proposional dan memdai.

2. Produk diklat yang berkualitas (Unggul) sesuai dengan kebutuhan pelanggan.

3. Organisasi dan menejemen yang efektif dan efisien, dengan birokkrasi yang praktis, didukung sistem informasi yang handal, serta dilandasi prinsi learning organization.

4. Dukungan dana yang sesuai dengan kebutuhan program.

5. Fasilitas yang sesuai dengan kebutuhan program diklat dan pengembangan lembaga.

\section{Stuktur Organisasi PPPPTK BISNIS DAN PARIWISATA}

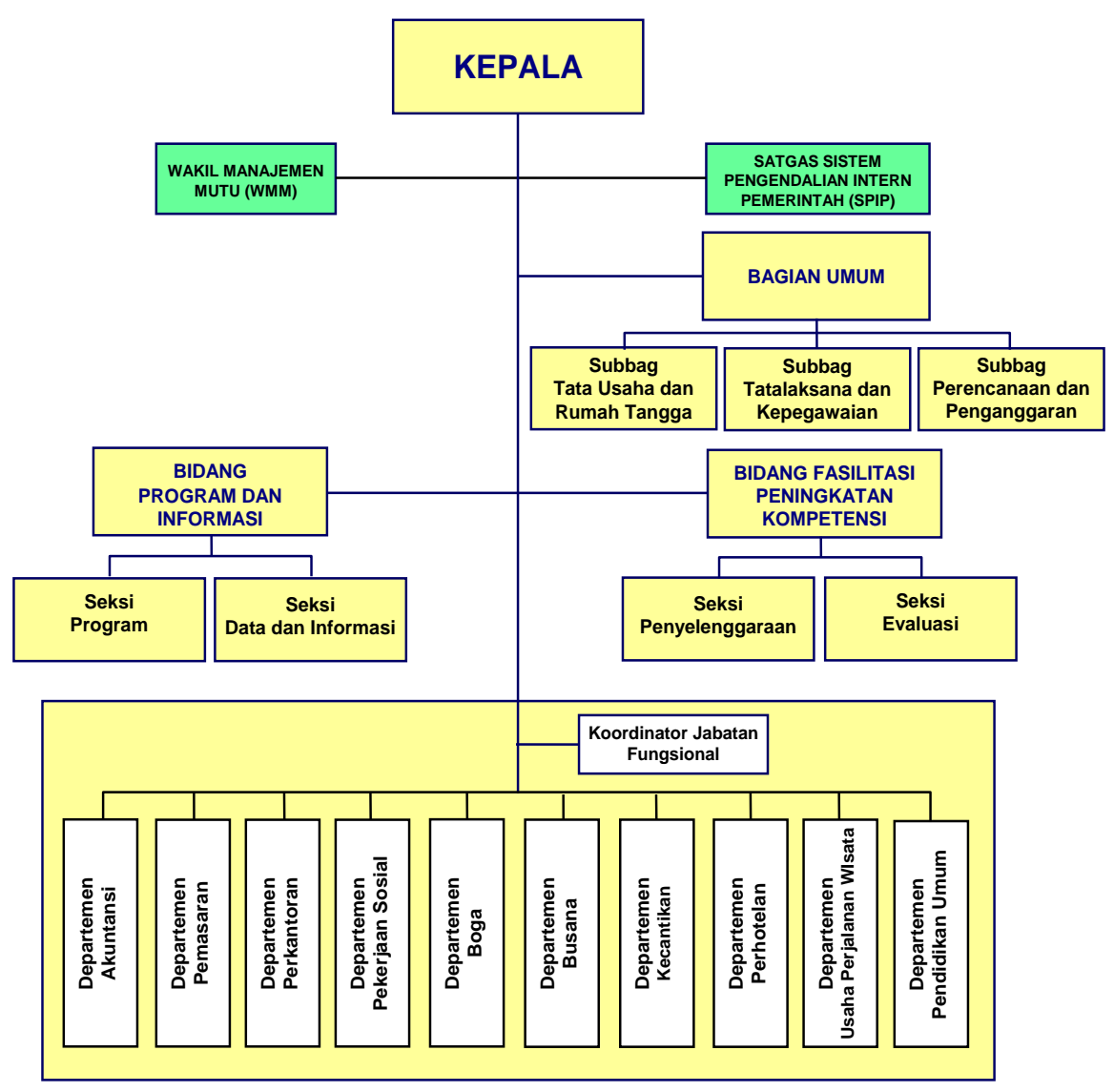




\section{Hasil dan Pembahasan Penelitian}

1. Tempat dan waktu pelaksanaan Pratek Kerja Lapangan

Tempat pelaksanaan praktek kerja lapangan adalah dikantor Pusat Pengembangan dan pemberdayaan pendidikan dan Tenaga Kependidikan(PPPPTK) Bisnis dan Pariwisata pada tanggal 26 Maret s.d 24 Mei 2013.

2. Pekerjaan yang dilakukan
a. Mengelola Surat Keluar
b. Mengarsip dan Menggandakan surat masuk dan surat keluar
c. Mengisi dan Menginformasikan jadwal keterkaitan dengan kegiatan kepala pusat
d. Menerima telepon dan fax masuk dari dalam dan luar instansi
e. Menerima tamu
f. Fotocopy, fax

3. Hasil yang diperoleh dari praktek kerja lapangan (PKL)
a. Mengetahui dunia kerja secara langsung
b. Mengetahui cara meningkatkan mutu kualitas kerja
c. Mengetahui pengoprasian peralatan dan mesin kantor
d. Mengtahui alur penglolaan surat keluar
e. Mengetahui cara menangani telepon masuk dan keluar

4. Masalah-masalah selama dalam melakukan pekerjaan

Dari hasil praktek kerja lapangan di kantor PPPPTK BISNIS DAN PARIWISATA penulis mendapatkan kesulitan dalam menghadapi pekerjaan khususnya dalam perusahaan adapun kendala yang dihadapi yaitu :

a. Dalam penerimaan telepon penulis kesulitan dalam menghadapi seseorang yang terburu - buru meminta file atau data.

b. Penulis kesulitan dalam pencariaan data yang sudah lama

c. Keterlambatan surat membuat penulis tidak mengetahui

Cara Mengatasinya:

a. Apabila ada seseorang yang terburu-buru, dengarkan baik-baik apa yang dibicarakan sehingga apa yang dimaksud orang itu dapat dipahami dan lalu bertanya apa yang orang inginkan.

b. Bertanya pada yang lebih mengerti dan lebih memahami kantor.

c. Jangan gugup dan bertanya kepada karyawan lain. 


\section{PENUTUP}

\section{Kesimpulan}

Berdasarkan uraian dan pembahasan pada bab-bab sebelumnya, maka dapat ditarik kesimpulan bahwa:

1. Dengan adanya peran Sekretaris, aktifitas perkantoran akan lebih efektif dan efisien.

2. Pada zaman era globalisasi, Sekretaris harus mengembangkan diri mengikuti perkembangan ilmu pengetahuan dan teknologi. Hal ini sangat penting bagi setiap orang.

3. Kemampuan berkomunkasi dan interaksi dengan pimpinan, pihak luar dan rekan bisnis merupakan peranan yang sangat penting bagi seorang sekretaris.

4. Dengan pelaksanaan tugas dan tanggung jawab pada setiap orang untuk menjadi lebih baik, harus ada motivasi atau semangat kerja.

\section{Saran}

Berdasarkan kesimpulan - kesimpulan yang telah dikemukakan, dapat diajukan beberapa saran untuk pengembangkan lebih lanjut antara lain:

1. Penulis mengharapkan upaya pengembangan sekretaris agar lebih mengembangkan dan meningkatkan mutu kualitas kerja tidak hanya berkaitan dengan pengetahuan dan ketrampilan, tetapi juga harus menyangkut kepribadian dan sikap mental.

2. Penulis mengharapkan Seorang Sekretaris harus memiliki kompetensi dalam dirinya, sehingga sekretaris dapat menyelesaikan tugas atau pekerjaannya dengan terampil, sikap kreatif, dan apresiasi yang diperlukan untuk menujang keberhasilan.

3. Penulis mengharapkan seorang sekretaris untuk dapat keberhasilan dalam pekerjaannya, maka seorang sekretaris harus pandai menyesuaikan diri, yakni kemampuan menempatkan diri pada situasi tertentu, memahami segala tugas yang menjadi kewajibannya sehingga dapat menghindari kesalahan.

4. Penulis mengharapkan seorang sekreatris memiliki integritas, kejujuran, dan loyalitas yang tinggi pada perusahaan dan pimpinan karena sifat pekerjaan sekretaris sangat berkaitan dengan kerahasiaan informasi perusahaan ataupun pribadi pimpinan. 


\section{DAFTAR PUSTAKA}

Ernawati, Ursula. PedomanLengkap Kesekretarisan. Edisi pertama. Yogyakarta: Penerbit Graha Ilmu. 20004

Hendarto, M.G. dan Hartiti dan F.X, Tulusharyono.Menjadi Sekretaris Profesional. Jakarta: Lembaga Manajemen PPM dan Penerbit PPM. 2003.

Rose, La.Top Secretary:Membangun Kepribadian dan Ketrampilan Menjadi Sekretaris Profesional. Jakarta: Erlngga. 2003.

Sedarmayanti.Tugas danPengembangan Sekretaris. Bandung: CV Mandur Maju.2005.

Triwidodo, Titiek dan Djoko Kristanto.Pengembangan Kepribadian Sekretaris. Jakarta: Gramedia Widiasarana Indonesia.2004.

Wursanto. Etika Komunikasi Kantor. Yogyakarta: Kanisius 2000.

Rismawaty, 2008," Kepribadian dan Etika Profesi”, Yogyakarta: Gajah Mada University Press

Farida, Vida Hasna dan Nurlela, Lilis. (2004) "Menggunakan Peralatan Kantor" Jilid I. Bandung: ARMICO

Departemen Pendidikan dan Kebudayaan, 1988 - mengutip dari Bertens 2000 